\title{
PEMANFAATAN APLIKASI AKUNTANSI BERBASIS ANDROID (SIAPIK) UNTUK MENINGKATKAN ADMINISTRASI KEUANGAN UMKM
}

\section{UTILIZATION OF ANDROID BASED ACCOUNTING APPLICATION (SIAPIK) TO IMPROVE FINANCIAL ADMINISTRATION OF MSMES}

\author{
L R Rinandiyana' ${ }^{1}$, D L Kusnandar ${ }^{1}$, A Rosyadi ${ }^{1}$ \\ 'Program Studi Menejemen, Universitas Siliwangi, Jl. Siliwangi No. 24 Tasikmalaya 46115 \\ ${ }^{a}$ Korespondensi: Lucky Radi Rinandiyana; E-mail: Luckyradi@unsil.ac.id \\ (Diterima: 03-10-2019; Ditelaah: 04-10-2019; Disetujui: 14-04-2020)
}

\begin{abstract}
One of the reasons for MSMEs being difficult to develop is a poor accounting system. There are still many MSMEs who do not want to think about complicated matters such as accounting and financial management issues. Financial administration that is well recorded will be able to optimize the professionalism of financial management. MSME sometimes do not even know in real terms the amount of money they have, how much capital is incurred, how much debt and receiveable, and whether their business has made a profit or even experienced a loss. This is the main problem why many MSMEs then do not get access to formal financial institutions. Existing access cannot be utilized because it turns out that MSMEs neglect to implement financial administration by standards. One of the efforts made by Bank Indonesia to encourage increased business capacity and access to MSMEs financing is to provide a standardized and simple means of recording financial transactions. Bank Indonesia has sought an Android-Based Accounting Applications (SiApik). This application is very easy to use and has met the MSMEs accounting standards. In connection with this, training and assistance were conducted on recording financial transactions and the use of SiApik to the owner of MSMEs in the Cibeuti Village, Kawalu City, Tasikmalaya. The implementation of this coaching will use focus group discussion methods, on-site training, and out site training. Through this training and assistance, it is expected that there will be an increase in understanding of financial records using SiApik.
\end{abstract}

Keyword: An android-based accounting application, financial records, si apik.

\begin{abstract}
ABSTRAK
Salah satu penyebab UMKM sulit berkembang adalah sistem akuntansi yang buruk. Berbagai faktor menjadi penyebab. Termasuk masih banyak pelaku UMKM yang tidak mau memikirkan hal rumit seperti masalah akuntansi dan manajemen keuangan.Administrasi keuangan yang tercatat dengan baik dapat mengoptimalkan sisi profesionalisme pengelolaan keuangan. Pengusaha UMKM terkadang tidak mengetahui secara riil jumlah uang yang dimiliki, berapa modal yang dikeluarkan, berapa hutang dan pihutang, serta apakah usaha mereka mendapatkan laba atau bahkan mengalami kerugian. Inilah yang menjadi pokok permasalah mengapa banyak UMKM yang tidak mendapatkan akses ke lembaga keuangan formal. Akses yang ada tidak dapat dimanfaatkan karena UMKM lalai untuk menerapkan administrasi keuangan sesuai standar. Salah satu upaya yang dilakukan oleh Bank Indonesia untuk mendorong peningkatan kapasitas usaha dan akses pembiayaan UMKM adalah dengan menyediakan sarana pencatatan transaksi keuangan yang terstandar dan sederhana. Bank Indonesia telah mengupayakan sebuah Aplikasi Akuntansi untuk UMKM berbasis Android. Aplikasi ini sangat mudah digunakan dan telah memenuhi
\end{abstract}


standar akuntansi Entitas Mikro Kecil Menengah (EMKM). Aplikasi ini bernama Si Apik. Sehubungan dengan hal tersebut dilakukan pelatihan dan pendampingan mengenai pencatatan transaksi keuangan dan penggunaan SiApik kepada pengelola UMKM di Kelurahan Cibeuti Kecamatan Kawalu Kota Tasikmalaya.Pelaksanaan pembinaan ini akan menggunakan metode focus group discussion, on site training maupun out site training. Melalui pelatihan dan pendampingan ini diharapkan terdapat peningkatan pemahaman pencatatan keuangan menggunakan sistem informasi aplikasi pencatatan informasi keuangan (SIAPIK) berbasis Android.

Kata kunci : Aplikasi akuntansi berbasis android, pencatatan keuangan,si apik.

Rinandiyana, L, R., Kusnandar, D, L., \& Rosyadi, A. (2019). Pemanfaatan Aplikasi Akuntansi Berbasis Anministrasi Keuangan UMKM. Jurnal Qardhul Hasan : Media Pengabdian kepada Masyarakat, 6(1), 73-78.

\section{PENDAHULUAN}

Pengembangan Usaha Mikro, Kecil dan Menengah (UMKM) haruslah dilakukan. Faktor penting dalam melakukan pengembangan usaha adalah pembukuan. Salah satu penyebab UMKM sulit berkembang adalah buruknya sistem akuntansi. Penyebabnya, pelaku UMKM tidak mau memikirkan akuntansi dan manajemen keuangan. Prioritas utama mereka adalah mendapatkan keuntungan.

Bermodal keuntungan, para pengusaha berharap usaha akan berkembang. Fokus ini yang mengakibatkan sebagian besar pengusaha kurang memperhatikan pencatatan keuangan. Inovasi yang dilakukan biasanya menyangkut produk atau layanan. Padahal salah satu peran penting dalam sebuah usaha adalah sisi administrasi termasuk administrasi keuangan.

Administrasi keuangan yang tercatat dengan baik akan dapat mengoptimalkan pengelolaan keuangan. Karena tanpa pencatatan yang baik, para pengusaha salah dalam mengambil keputusan. Pengusaha UMKM terkadang tidak mengetahui secara riil jumlah uang yang dimiliki, berapa modal, berapa hutang dan piutang, serta apakah telah mendapatkan laba atau mengalami kerugian.

Administrasi keuangan yang baik dapat membuka akses permodalan usaha.
Seringkali faktor yang menjadi keluhan adalah kurangnya modal yang dimiliki. Sumber modal dapat dipenuhi melalui dua alternatif, yaitu modal sendiri dan asing. Mengingat keterbatasan yang ada, opsi menggunakan modal asing tentunya dapat menjadi pilihan.

Apalagi saat ini banyak program dari pemerintah dan lembaga swasta dalam pemberian kredit bagi UMKM. Masalahnya adalah semua program kredit mengharuskan administrasi keuangan sesuai standar.

Inilah yang menjadi masalah mengapa banyak UMKM yang tidak mendapatkan akses ke lembaga keuangan formal. Akses yang ada tidak dapat dimanfaatkan karena UMKM lalai menerapkan administrasi keuangan sesuai standar.

PengusahaUMKM harus diberi kesadaran agar memahami bahwa administrasi keuangan akan bermanfaat bagi keberlangsungan usaha. Penerapan administrasi keuangan sesuai standar bukan faktor yang harus ditakuti. Ketakutan muncul karena ada pemikiran tidak akan mampu mengikuti proses pembelajaran pembuatan administrasi keuangan.

Dunia digital yang tumbuh membawa dampak pada kemudahan pelaku usaha untuk membuat pencatatan transaksi keuangan. Pihak-pihak yang berkepentingan dalam pengembangan UMKM turut memanfaatkan dunia digital untuk mempermudah pelaku UMKM melakukan 
administrasi keuangan sesuai standar. Berbagai software telah dirilis untuk digunakan. Hal ini juga menjadi perhatian bagi Bank Indonesia.

Upaya yang dilakukan oleh Bank Indonesia untuk mendorong peningkatan kapasitas usaha dan akses pembiayaan UMKM adalah dengan menyediakan sarana standar pencatatan transaksi keuangan dan sederhana. Bank Indonesia bekerjasama dengan Ikatan Akuntan Indonesia (IAI) menyusun pedoman Pencatatan Tranaksi Keuangan (PTK), sehingga diperoleh hasil berupa Pedoman Umum, Pedoman Teknis, serta Modul Pelatihan PTK bagi UMK. Pedoman ini telah dikonfirmasi kepada perbankan sehingga telah memenuhi kaidah dan persyaratan perbankan dalam melakukan penilaian kelayakan kredit UMK. Bank Indonesia telah mengupayakan sebuah Aplikasi Akuntansi untuk Usaha Mikro Kecil berbasis Android. Aplikasi ini sangat mudah digunakan dan telah memenuhi standar akuntansi Entitas Mikro Kecil Menengah (EMKM). Aplikasi ini bernama Si Apik.

Aplikasi Si Apik dapat diunduh secara gratis di Google Play Store. Dengan kemudahan yang dimiliki, diharapkan pelaku UMKM dapat memanfaatkan aplikasi ini secara optimal agar administrasi keuangan menjadi lebih baik sesuai standar dan membuka akses ke berbagai lembaga keuangan.

Sehubungan dengan itu, kami bermaksud memberikan pelatihan dan pendampingan pencatatan transaksi keuangan dan penggunaan SiApik kepada pengelola Wawan Service di Kelurahan Cibeuti Kecamatan Kawalu Kota Tasikmalaya dengan judul PKM "Pemanfaatan Aplikasi Akuntansi Berbasis Android (SiApik) untuk Meningkatkan Administrasi Keuangan UMKM “.

\section{MATERI DAN METODE}

Pelaksanaan pembinaan ini akan menggunakan metode focus group discussion (FGD), on site training maupun out site training yang akan dilaksanakan selama kurang lebih empat bulan. Mitra pelatihan (pengusaha UMKM) akan dikunjungi oleh pengusul beserta tenaga ahli sesuai bidang yang dibutuhkan untuk memberikan pembinaan dan pelatihan.

Materi pelatihan yang akan diberikan antara lain :

Pelatihan dan pembinaan pencatatan transaksi keuangan; Pelatihan dan pembinaan pembuatan laporan keuangan; Pelatihan dan pembinaan analisa sederhana terhadap laporan keuangan; Pelatihan pemanfaatan Aplikasi Akuntansi Usaha Mikro Kecil (UMK) berbasis Android.

Pelaksanaan kegiatan pengabdian ini terdiri dari analisis awal, persiapan, pelaksanaan, dan evaluasi. Dalam proses persiapan penekanan kegiatan adalah untuk mengetahui secara lebih mendalam kondisi yang ada di mitra meliputi proses pembelajaran, sistem pengelolaan administrasi keuangan, fasilitas perusahaan dan kemampuan pencatatan transaksi keuangan terutama dalam hal pemanfaatan software berbasis Android.

Kemudian dalam proses persiapan dilakukan penyusunan metode pelatihan sesuai hasil evaluasi awal, penyedia software yang dibutuhkan, penyiapan media alternatif untuk mendukung proses pembelajaran terutama yang berbasis elearning/internet, serta mempersiapkan berbagai prosedur pelatihan dan pendampingan. Pada tahap pelaksanaan kegiatan dilakukan instalasi software yang dibutuhkan, pelatihan, simulasi pembelajaran multimedia dan simulasi pencatatan transaksi keuangan dengan memanfaatkan Aplikasi Akuntansi Usaha Mikro Kecil (UMK) berbasis Android. Pada keseluruhan tahap selalu disertai dengan proses pengendalian.

\section{HASIL DAN PEMBAHASAN}

Pengelolaan UMKM memiliki tantangan tersendiri. Berbagai keterbatasan yang dimiliki tidak membuat para pelaku UMKM 
menyerah dalam menghadapi tantangan yang ada. Fokus para pelaku UMKM biasanya ada pada aspek produksi dan pemasaran. Mereka seringkali memikirkan bagaimana caranya agar memiliki produk yang mampu menarik perhatian pasar, dan mengupayakan cara agar produk mereka dapat laku untuk dijual.

Fokus ini mengalihkan mereka pada aspek lain dalam pengelolaan perusahaan, yaitu pencatatan transaksi keuangan sebagai bagian dari administrasi keuangan perusahaan. Pencatatan yang baik akan membuat pelaku UMKM dengan mudah mengetahui kondisi keuangan usaha mereka. Pencatatan keuangan yang sesuai dengan standar pun akan dapat membuka peluang bagi UMKM untuk memperoleh akses pembiayaan ke berbagai lembaga keuangan. Terlebih lagi pada saat ini banyak sekali program yang dapat dimanfaatkan untuk menambah modal demi perkembangan usaha.

Proses untuk mempelajari bagaimana pencatatan transaksi keuangan sesuai standar tentu merupakan langkah awal yang baik untuk memperbaiki aspek administrasi pengelolaan UMKM. Pencatatan transaksi keuangan tidak perlu lagi dilakukan secara manual. Mengingat tingkat penggunaan telepon seluler berbasis andrid yang semakin meningkat, tentunya merupakan sebuah keuntungan tersendiri karena pada saat ini telah tersedia Aplikasi Akuntansi Usaha Mikro Kecil (UMK) berbasis Android yang disediakan secara gratis oleh Bank Indonesia bekerjasama dengan Ikatan Akuntan Indonesia (IAI). Aplikasi ini akan semakin mempermudah pelaku UMKM untuk mencatat transaksi keuangan mereka. Untuk itu perlu tenaga pengelola yang mengerti pencatatan transaksi keuangan. Apabila tenaga pengelola yang ada belum mampu secara maksimal melakukan kegiatan pencatatan transaksi keuangan, dapat dilakukan dengan meningkatkan kualitas pengelola melalui pelatihan. Hal ini sesuai dengan prinsip human capital theory yang menyatakan bahwa pendidikan dan pelatihan adalah cara utama untuk meningkatkan investasi pada diri manusia menuju kesejahteraan.

Dapat diidentifikasi beberapa permasalahan yang ada dalam pengelolaan UMKM apabila dilihat dari sisi manajemen keuangan sebagai berikut : Keterbatasan pengetahuan pengelola terhadap bagaimana pencatatan transaksi keuangan; Kemampuan mengelola pencatatan transaksi keuangan untuk kemudian disampaikan dengan membuat laporan keuangan; Pembuatan analisa sederhana terhadap kondisi keuangan perusahaan.

Pemanfaatan Aplikasi Akuntansi Usaha Mikro Kecil (UMK) berbasis Android sebagai alternatif pencatatan transaksi keuangan.

Dari permasalahan yang telah diuraikan sebelumnya, maka salah satu cara untuk meningkatan kemampuan pengusaha UMKM di bidang manajemen keuangan adalah dengan cara memanfaatkan Aplikasi Akuntansi Usaha Mikro Kecil (UMK) berbasis Android. Dengan penggunaan aplikasi ini, diharapkan akan mampu memberikan informasi dengan lebih jelas dan tepat, sehingga akan memperbaiki pengelolaan usaha yang dijalani. Selain itu juga diharapkan untuk memperluas akses kepada berbagai fasilitas pembiayaan yang disediakan lembaga keuangan agar usaha yang dijalani menjadi semakin berkembang. Dari fenomena tersebut,maka alternatif solusinya adalah : Melakukan evaluasi terhadap pencatatan transaksi yang selama ini diterapkan; Menyusun ulang pencatatan transaksi yang akan diterapkan; Mencari alternative sistem pencatatan transaksi untuk mendukung pembuatan laporan keuangan sesuai standar yang ada; Memberikan pelatihan mengenai pencatatan transaksi keuangan; Memberikan materi mengenai pembuatan laporan keuangan; Memberikan pelatihan untuk membuat analisa sederhana terhadap laporan keuangan; Memberikan pelatihan mengenai pemanfaatan Aplikasi Akuntansi Usaha Mikro Kecil (UMK) berbasis Android. 
Dari hasil kesimpulan masalah dan solusi yang direncanakan bersama pihak pengusaha, maka Program Kerja yang menjadi Prioritas utama adalah :Pelatihan dan pembinaan pencatatan transaksi keuangan; Pelatihan dan pembinaan pembuatan laporan keuangan; Pelatihan dan pembinaan membuat analisa sederhana terhadap laporan keuangan.

Pelatihan mengenai pemanfaatan Aplikasi Akuntansi Usaha Mikro Kecil (UMK) berbasis Android. Target dari kegiatan ini adalah : Peningkatan kapasitas SDM melalui intervensi berupa FGD dan pelatihan/ pendampingan; Meningkatnya kualitas pencatatan transaksi keuangan.

Meningkatnya kualitas pembuatan laporan keuangan; Meningkatnya kualitas pembuatananalisa sederhana terhadap laporan keuangan; Meningkatnya kemampuan pemanfaatan Aplikasi Akuntansi Usaha Mikro Kecil (UMK) berbasis Android; Kegiatan Pengabdian pada Masyarakat dilaksanakan 2 tahap, yaitu Tahap I melakukan kegiatan pelatihan pada Maret s/d April 2019. Materi yang disampaikan pada saat pelatihan yaitu dasar-dasar pencatatan keuangan, instalasi software dan simulasi sistem informasi aplikasi pencatatan informasi keuangan (SIAPIK) berbasis android. Sedangkan Tahap II dilakukan bulan Mei s/d Juli 2019 .Tahap II dilakukan pendampingan dengan tujuan untuk melihat pengaplikasian dari hasil pelatihan pada Tahap I. Pada Tahap II, pemilik dan karyawan Mitra PKM wajib mencatat setiap transaksi yang terjadi pada bulan Mei sampai dengan Juli 2019. Pencatatan keuangan tersebut dilakukan dengan bantuan software SIAPIK yang telah di instal pada gadget pemilik dan karyawan Mitra PKM.

\section{KESIMPULAN}

Untuk mengoptimalkan peran pemerintah dalam mendukung kegiatan perekonomian masyarakat, maka dilakukan pelatihan dan pendampingan pada pelaku UMKM. Kegiatan yang dapat dilakukan dapat memanfaatkan berbagai kemajuan di bidang teknologi informasi. Tingkat penggunaan smartphone yang semakin tinggi di masyarakat dapat dijadikan sebagai media untuk meningkatkan kemampuan masyarakat dalam berbagai bidang. Khususnya untuk UMKM masalah yang sering muncul adalah dalam hal pencatatan informasi keuangan. Dengan adanya pelatihan dan pendampingan ini diharapkan terdapat peningkatan pemahaman pencatatan keuangan menggunakan sistem informasi aplikasi pencatatan informasi keuangan (SIAPIK) berbasis Android. Selain itu pencatatan keuangan yang sesuai dengan standar akan menambah akses bagi UMKM pada lembaga keuangan resmi.

Berdasarkan kesimpulan diatas maka Saran yang disampaikan adalah :

\section{Bagi Pemilik Usaha}

Pemilik Usaha hendaknya melakukan perubahan pola pikir bahwa usaha apapun bila dikelola dengan tepat dapat memberikan hasil yang optimal. Pelatihan yang sudah diberikan sebaiknya diterapkan dan diaplikasikan secara bertahap dan terus menerus, sehingga program pelatihan ini dapat mermberikan manfaat bagi kemajuan usaha kelompok tersebut.

\section{Bagi Lembaga (Perguruan Tinggi)}

Sebaiknya Program Pengabdian Kepada Masyarakat (PKM) ini dilakukan secara berkala dan kontinyu, agar ada kesinambungan antara program yang satu dengan yang lainnya. Dengan adanya kesinambungan program ini diharapkan memberikan manfaat yang optimal kepada seluruh masyarakat, khususnya yang menjadi subjek Pengabdian Kepada Masyarakat.

Sehubungan adanya keterbatasan dalam Pelatihan dan Pendampingan ini, tidak semua pelaku UMKM bisa mengikuti pelatihan dan pendampingan maka dari itu program Pengabdian Kepada Masyarakat (PKM) tahap berikutnya adalah memberikan Pelatihan dan Pendampingan 
secara lebih luas. Dengan demikian diharapkan seluruh pelaku UMKM dapat memanfaatkan sistem informasi aplikasi pencatatan informasi keuangan (SIAPIK) untuk mempermudah pelaku UMKM dalam poses pencatatan keuangan yang akhirnya dapat menghasilkan laporan keuangan sesuai standar..

\section{UCAPAN TERIMAKASIH}

Pengabdian Kepada Masyarakat dengan judul "Pemanfaatan Aplikasi Akuntansi Berbasis Android (SiApik) untuk Meningkatkan Administrasi Keuangan UMKM" dapat diselenggarakan dengan baik karena dukungan berbagai pihak. Untuk itu kami mengucapkan terima kasih dan penghargaan sebesar-besarnya kepada :Rektor Universitas Siliwangi Tasikmalaya.Dekan Fakultas Ekonomi Universitas Siliwangi Tasikmalaya.

Ketua LP2MP-PMP Universitas Siliwangi Tasikmalaya; Pemilik Wawan Service, pelaku UMKM di Kelurahan Cibeuti Kecamatan Kawalu Kota Tasikmalaya; Pihak lain yang tidak dapat kami sebutkan satu persatu.

\section{DAFTAR PUSTAKA}

Bank Indonesia dan Ikatan Akuntan Indonesia, 2015, Modul Pencatatan Transaksi Keuangan Usaha Kecil Badan Usaha Bukan Badan Hukum Sektor Jasa , Bank Indonesia.
Kartawan, 2016, Pemberdayaan UMKM Untuk Meningkatkan Kesejahteraan Masyarakat, Penerbit LPPM Universitas Siliwangi

Kartawan., Rinandiyana, Lucky Radi., Kurniawan. Dian. (2016), Pengembangan Usaha Melalui Peningkatan Kemampuan Bersaing Produk UMKM Dalam Memasuki Masyarakat Ekonomi Asean. Jurnal Ekonomi Bisnis Volume 21 No.2, Agustus 2016.

Kartawan, 2012, Kewirausahaan Untuk Para Calon Entrepreneur, Guardaya Intimartha, Bandung.

Muh.Islah, Hasyim, Muhammad Jayadi, Mursalim Sila, Ibm Pelatihan Penyusunan Laporan Keuangan Usaha Kecil Menengah, Prosiding Seminar Hasil Pengabdian Kepada Masyarakat (SNP2M) 2017 (Pp.262-265).

Wilfried Seth Manoppo, Frendy A. O. Pelleng, Pelatihan Penyusunan Laporan Keuangan Dengan Teknik Pembukuan Sederhana Bagi Pelaku Usaha UMKM Di Kecamatan Malalayang Kota Manado Provinsi Sulawesi Utara, Jurnal Administrasi Bisnis Vol. 7. NO. 2, 2018. 